\title{
Physical characterization of fruits and seeds Inga laurina (Sw.) Willd. (Fabaceae - Mimosaceae)
}

\author{
Carlos Eduardo da Silva Oliveira ${ }^{1}$, Alan Mário Zuffo², Wéverson Lima Fonseca ${ }^{3}$, Fábio \\ Steiner ${ }^{1}$
}

${ }^{1}$ Universidade Estadual de Mato Grosso do Sul, Unidade Universitária de Cassilândia, Cassilândia, Mato Grosso do Sul, Brasil. E-mail: carllos_eduard@hotmail.com, steiner@uems.br

${ }^{2}$ Universidade Federal de Mato Grosso do Sul, Campus de Chapadão do Sul, Chapadão do Sul, Mato Grosso do Sul, Brasil. E-mail: alan_zuffo@hotmail.com

${ }^{3}$ Universidade Federal do Ceará, Centro de Ciências Agrárias, Fortaleza, Ceará, Brasil. E-mail: weversonufpi@gmail.com

Received: 17/09/2018; Accepted: 24/06/2019.

\begin{abstract}
The main physical and morphological characteristics of Inga laurina (Sw.) Willd. (Fabaceae -Mimosaceae) fruits and seeds, and correlation estimates between these characteristics were investigate in this study. Mature fruits of $I$. laurina were collected from matrices trees established in a savannah area located at the municipality of Cassilândia, Mato Grosso do Sul, Brazil. The length, width, and thickness of 100 fruits and 100 seeds were measured. The fresh mass of fruits, pulp and seeds, and seed number per fruit were quantified. Data were analyzed by using descriptive statistics, adjustment of statistical distributions, and Spearman's rank correlation analysis (rS). The I. laurina presents variation in the size and weight of fruits, pulp, and seeds, which can be explored for breeding programs and should be considered in the formation of seed lots that are more homogeneous. The fruits of I. laurina species are composed of $41 \%$ of pulp, $39 \%$ of bark and $20 \%$ of the seed. The greater fruit pulp yield can be optimized with the selection of fruits with greater fresh mass and longer due to the high degree of association between these characteristics and the pulp yield. The fruit length is a good indication in the selection of seeds with greater weight.
\end{abstract}

Keywords: guama, Brazilian Savannah, pulp yield, morphological.

\section{Caracterização física de frutos e sementes de ingá-mirim [Inga laurina (Sw.) Willd.] (Fabaceae - Mimosaceae)}

\section{RESUMO}

Neste estudo foram avaliadas as principais características físicas e biométricas dos frutos e das sementes de ingámirim [Inga laurina (Sw.) Willd.] (Fabaceae - Mimosaceae), estabelecendo-se estimativas de correlação entre essas variáveis. Os frutos maduros de I. laurina foram coletados em árvores matrizes estabelecidas em uma área de Cerrado localizada no município de Cassilândia (MS). Mediu-se o comprimento, largura e espessura de 100 frutos e de 100 sementes de I. laurina. Quantificaram-se a massa fresca dos frutos, da polpa e das sementes, e o número de sementes por fruto. Os dados foram analisados por meio de estatística descritiva, de ajuste de distribuições estatísticas e de análise de correlação de Spearman (rS). O ingá-mirim apresenta variação no tamanho e no peso dos frutos, polpa e sementes, que podem ser exploradas nos programas de melhoramento genético e devem ser consideradas na formação de lotes de sementes homogêneas. Os frutos da espécie I. laurina são constituídos de $41 \%$ de polpa, 39\% de casca e $20 \%$ de semente. O maior rendimento de polpa dos frutos pode ser otimizado com a seleção de frutos com maior massa fresca e mais compridos, devido ao alto grau de associação entre essas características e o rendimento de polpa. O comprimento do fruto é um bom indicador na seleção de sementes com maior peso.

Palavras-chave: ingá, Cerrado, rendimento de polpa, morfometria. 
Inga laurina (Sw.) Willd, Fabaceae - Mimosaceae, commonly known as 'ingá-mirim' or 'guama', is a tropical fruit tree native to Brazil. It is a perennial tree with a dense, low, rounded crown, that can be found from Mexico south to Argentina. In Brazil, I. laurina is commonly planted as a shade tree for coffee and cocoa plantations and is sometimes grown as an ornamental plant. Inga laurina trees start flowering from August to December. The fruits develop by December to March and are flat up to $140 \mathrm{~mm}$ long and $40 \mathrm{~mm}$ wide, fleshy, and edible; each fruit contains on average seven seeds. The fruit pulp is white, slightly fibrous and rich in mineral salts. The edible fruit is sometimes gathered from the wild for local use (Lorenzi, 2002; Lorenzi et al., 2006).

Inga laurina has great importance for Brazilian flora due to its ornamental and forest value because its fruits are a source of food for wild animals (Souza and Lorenzi, 2005). The use of seeds is the most widely used method for the propagation of I. laurina plants. However, as this species produces recalcitrant seeds, sexual propagation is hampered because the seed viability under natural conditions is extremely short, not longer than 15 days (Fonseca and Freire, 2003; Bonjovani and Barbedo, 2008). Therefore, the seeds of this species cannot be stored for long periods. Despite the importance of the species, there are few studies on the morphology of fruits and seeds, important traits for the germination process (Schulz et al., 2014).

The large variability existing in tree species of the genus Inga sp. with respect to the morphological and physical traits of fruits and seeds has hampered the identification of species that occur in Brazil. The genus Inga Mill. is one of the largest subfamilies Mimosoideae (Leguminosae) with about 300 species, and of these, 131 species occur in Brazil and 48 species occur in the Cerrado region (Pennington, 1997). These morphological studies are important to aid in the characterization of families or species of the same genus plants (Lorenzi et al., 2006; Zuffo et al., 2016), identification and certification of plant material used in seed analysis (Gusmão et al., 2006) and to contribute in studies of ecological succession and regeneration of forest ecosystems (Rodrigues et al., 2008; Rebouças et al., 2008). Therefore, analyses of the morphological traits of fruits and seeds are necessary due to the importance of these structures in the botanical identification and propagation of the species (Aquino et al., 2009).

An improved understanding of tropical tree species is a requirement for their use in commercial plantation and agroforestry systems (Gusmão et al., 2006). Therefore, the objective of this study was to determine the main physical characteristics of the I. laurina (Sw.) Willd. (Fabaceae-Mimosaceae) fruits and seeds, and to establish the correlations estimates among these characteristics.

Mature fruits of I. laurina (Sw.) Willd. ("ingamirim") were collected from trees established in a savanna area located at the municipality of Cassilândia, Mato Grosso do Sul, Brazil (1905'20" S, 5148'24" W, and altitude of $480 \mathrm{~m}$ ), during the rainy season, in March 2016. Fruits of Inga laurina are considered mature when the bark has yellow coloration (Schulz et al., 2014). The regional climate according to the Köppen classification is Aw, characterized as a tropical climate with hot summers and a tendency towards high rainfall levels, and dry winters, with a dry season between May and September. The 30-year mean annual temperature is $24.1{ }^{\circ} \mathrm{C}$ with a July minimum of $16.4{ }^{\circ} \mathrm{C}$ and a January maximum of $28.6^{\circ} \mathrm{C}$, and mean annual rainfall of $1,520 \mathrm{~mm}$. Temperature and rainfall data gathered during the flowering period (from September to November) and fruit develop (December to February) of Inga laurina (Sw.) Willd. in the years 2015 and 2016 are shown in Figure 1.

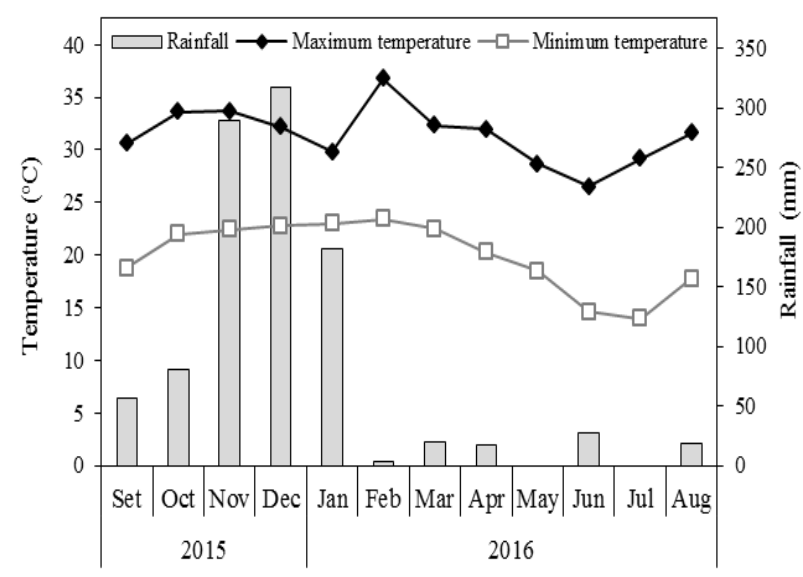

Figure 1. Minimum and maximum temperature $\left({ }^{\circ} \mathrm{C}\right)$ and total monthly rainfall $(\mathrm{mm})$ occurred during the flowering period and fruit develop of Inga laurina (Sw.) Willd. in the years 2015 and 2016. Fonte: Meteorological Station of the National Institute of Meteorology - INMET. Cassilândia, MS, Brazil.

The fruits were placed in polyethylene bags and taken to the Crop Science Laboratory of State University of Mato Grosso do Sul (UEMS), in Cassilândia, MS, where the study was carried out immediately. In the laboratory, the fruits were previously selected, discarding those visually impaired or deformed, and a sample of 100 fruits was taken for measurement of physical characteristics.

The length (FL), width (FW), and thickness (FT) of fruits were measured using a digital caliper with \pm 0.01 $\mathrm{mm}$ accuracy. The fruit (FFM) and pulp fresh mass (PFM), in grams, was obtained by individual weighing in a digital precision balance with $210 \mathrm{~g}$ capacity and $0.0001 \mathrm{~g}$ accuracy. Pulp mass was calculated as a percentage of the fruit mass. 
After the physical characterization of the fruits, the seeds were manually extracted and then the length (SL), width (SW), thickness (ST) and fresh mass (SFM) of seeds were measured from a sample of 100 seeds using a digital caliper and a digital precision balance.

The morphological data of the fruits and seeds were analyzed using the adjustment of statistical distributions and descriptive statistics, who understood the measurements of position (average, minimum and maximum values) and dispersion (coefficient of variation, skewness, kurtosis, mean standard error and standard deviation). The Spearman's correlation coefficients (rS) were estimated at the level of $5 \%$ probability for the association between the morphological traits of fruits and seeds using the t-test (Zar, 1996). All analyses were performed using Bioestat ${ }^{\circledR}$ version 5.0 software for Windows (Ayres et al., 2007).

Fruits of I. laurina (Sw.) Willd. presented average dimensions of $83.67 \mathrm{~mm}$ of length, $22.05 \mathrm{~mm}$ of width, $20.66 \mathrm{~mm}$ of thickness and $21.28 \mathrm{~g}$ of fresh mass (Table 1). The seeds have $17.58 \mathrm{~mm}$ of length, $10.04 \mathrm{~mm}$ of width, $8.32 \mathrm{~mm}$ of thickness and $0.95 \mathrm{~g}$ of fresh mass. The pulp represents about $41 \%$ of the fresh weight of the fruit, with an average value of $8.91 \mathrm{~g}$, whereas the bark and seeds represent about $39 \%$ and $20 \%$ of the fruit fresh weight of the, respectively. These characteristics were similar to I. laurina (Sw.) Willd. fruits collected in the southern region of Brazil, in Marechal Cândido Rondon, PR, Brazil that had $76.80 \mathrm{~mm}$ of length, 19.0 $\mathrm{mm}$ of width, and fresh mass of $19.77 \mathrm{~g}$, whereas the seeds weighed $1.01 \mathrm{~g}$, and had $10.0 \mathrm{~mm}$ long and 7.90 $\mathrm{mm}$ wide (Schulz et al., 2014). For the species Inga striata Benth., Mata et al. (2013) reported higher values for the morphological traits of fruits and seeds, with fruit length, width and thickness of $185.80 \mathrm{~mm}, 21.86$ $\mathrm{mm}$ and $18.20 \mathrm{~mm}$, respectively, while for seeds the length, width, and thickness values were $15.52 \mathrm{~mm}$, $10.64 \mathrm{~mm}$, and $5.34 \mathrm{~mm}$, respectively.
The skewness and kurtosis values were close to zero (i.e., lower than \pm 1.0 ) for all physical characteristics of the fruits and seeds, except for the fresh pulp mass. These findings indicate an approximately normal distribution for these variables. Evaluating the morphological characteristics of the fruit and seeds of maripa palm [Attalea maripa (Aubl.) Mart.], Zuffo et al. (2016) also showed normal distribution for all measured variable, except for pulp water content. The normal distribution for the variables measured in the studies of morphological characterization of fruits and seeds has commonly been reported by other species of fruit trees, such as in jambolan [Syzygium cumini (L.) Skeels] (Steiner et al., 2017), baru [Dipteryx alata Vog.] (Zuffo et al., 2014), and canafistula (Peltophorum dubium (Sprengel) Taubert] (Zuffo et al., 2017).

The values of the coefficients of variation $(\mathrm{CV})$ ranging from $7.38 \%$ to $47.60 \%$ for fruit traits and 8.83 to $15.54 \%$ for seed traits. Coefficients of variation for fruit width $(7.52 \%)$, fruit thickness $(7.38 \%)$ and seed length $(8.83 \%)$ indicated that the data obtained in these variables have a more homogeneous distribution (less dispersed) compared to the other measured variables whose values of coefficients of variation were greater than $10 \%$. The values of the CV presented here were similar to values reported by Zuffo et al. (2014) to the physical characteristics of baru (Dipteryx alata Vog.), Zuffo et al. (2016) in fruits and seeds of tarumarana (Buchenavia tomentosa Eichler) and maripa palm (Attalea maripa), and Zuffo et al. (2017) in canafistula (Peltophorum dubium (Sprengel) Taubert).

Regarding the relative frequency distribution for fruit characteristics, $71 \%$ of the fruits have length comprised within three size classes - i.e., from 66 to $108 \mathrm{~mm}$ (Figure 2a). For the fruit width and thickness, around $63 \%$ and $71 \%$ of the fruits have width and thickness comprised within two size classes - i.e., from 21.0 to $24.0 \mathrm{~mm}$ (Figure 2b) and 19.0 to $22.0 \mathrm{~mm}$ (Figure 2c), respectively.

Table 1. Physical characteristics of the fruits and seeds of Inga laurina (Sw.) Willd. (Fabaceae-Mimosaceae).

\begin{tabular}{|c|c|c|c|c|c|c|c|}
\hline Characteristic & Average $^{1}$ & Minimum & Maximum & Skewness & Kurtosis & SD & $\mathrm{CV}(\%)$ \\
\hline & \multicolumn{7}{|c|}{ Fruit } \\
\hline Fruit length (mm) & $83.67 \pm 1.85$ & 38.20 & 120.40 & -0.15 & -0.50 & 18.51 & 22.13 \\
\hline Fruit width (mm) & $22.05 \pm 0.16$ & 18.60 & 26.60 & 0.19 & -0.47 & 1.62 & 7.52 \\
\hline Fruit thickness (mm) & $20.66 \pm 0.15$ & 16.00 & 24.80 & -0.01 & 0.98 & 1.52 & 7.38 \\
\hline Fruit fresh mass (g) & $21.28 \pm 0.71$ & 8.07 & 42.99 & 0.53 & -0.12 & 7.17 & 33.74 \\
\hline Pulp fresh mass (g) & $8.91 \pm 4.22$ & 1.43 & 24.25 & 1.10 & 2.44 & 4.22 & 47.60 \\
\hline Bark fresh mass (g) & $8.29 \pm 2.76$ & 3.21 & 17.8 & 0.76 & 1.21 & 3.84 & 28.44 \\
\hline \multirow[t]{2}{*}{ Number of seeds } & $4.47 \pm 0.15$ & 1.00 & 9.00 & 0.28 & -0.15 & 1.58 & 35.47 \\
\hline & \multicolumn{7}{|c|}{ Seed } \\
\hline Seed length (mm) & $17.58 \pm 0.15$ & 12.72 & 20.56 & -0.48 & -0.12 & 1.55 & 8.83 \\
\hline Seed width (mm) & $10.04 \pm 0.12$ & 7.60 & 12.64 & 0.21 & -0.70 & 1.26 & 12.56 \\
\hline Seed thickness (mm) & $8.32 \pm 0.08$ & 6.38 & 10.53 & 0.12 & -0.49 & 0.85 & 10.31 \\
\hline Seed fresh mass (g) & $0.95 \pm 0.08$ & 0.56 & 1.20 & -0.30 & -0.09 & 0.11 & 15.54 \\
\hline
\end{tabular}

${ }^{1}$ Data refer to mean values $(\mathrm{n}=100) \pm$ mean standard error. SD: standard deviation. $\mathrm{CV}$ : coefficient of variation. 

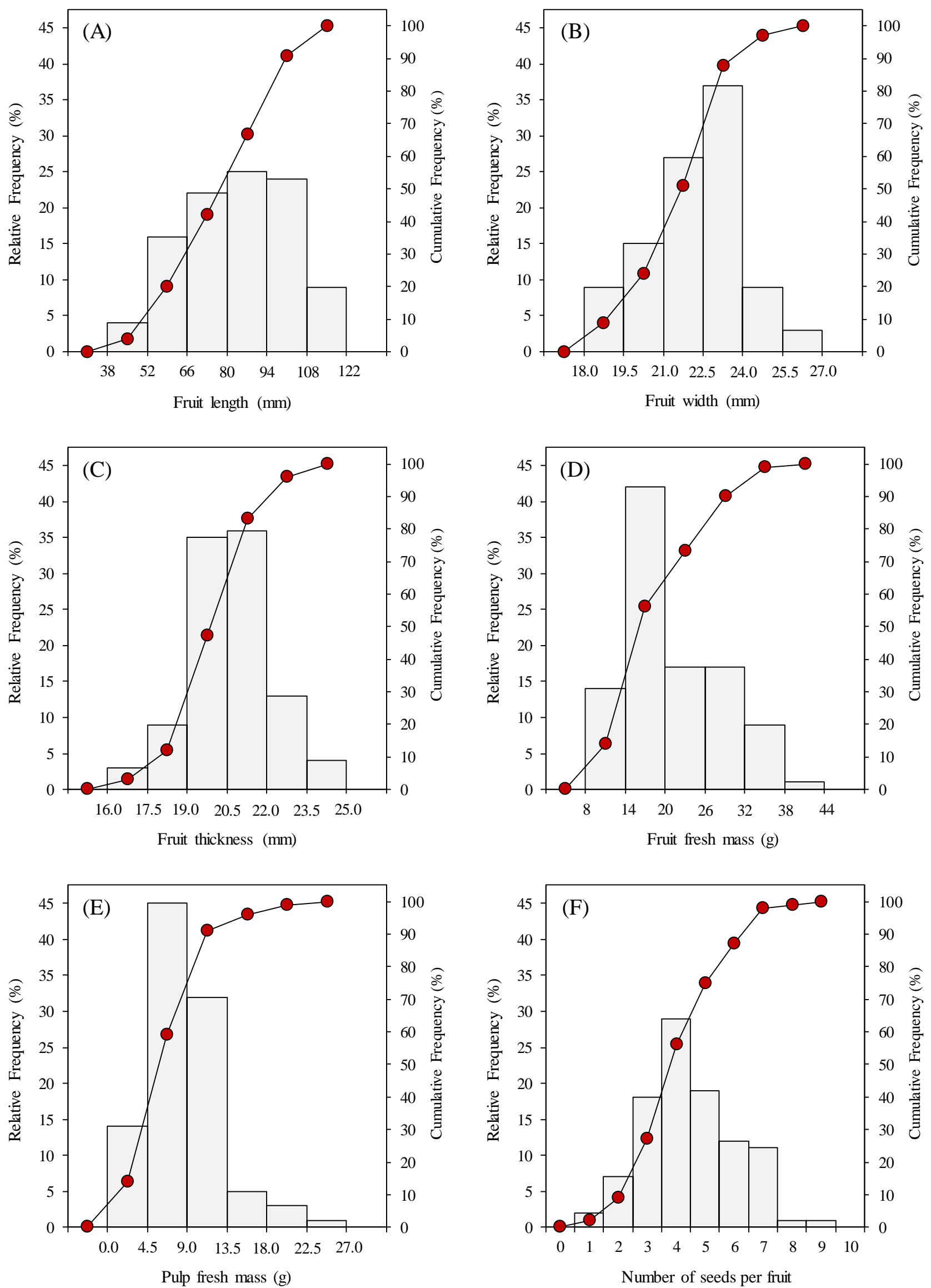

Figure 2. Distribution of relative and cumulative frequencies for the different physical characteristics of the fruits: a) length (FL), b) width (FW), c) thickness (FT), d) fresh mass (FFM), e) pulp fresh mass (PFM), and f) number of seeds per fruit (NSF) of Inga laurina (Sw.) Willd. (Fabaceae - Mimosaceae) collected in the municipality of Cassilândia, MS, Brazil. N = 100 fruits. 
For the fruit fresh mass, $42 \%$ of the fruits have mass in the range of 14.0 to $20.0 \mathrm{~g}$ (Figure 2d). The pulp fresh mass ranging from 1.43 to $24.25 \mathrm{~g}$ (Table 1), with $77 \%$ of the fruits presenting values in two pulp yield classes between 4.5 to $13.5 \mathrm{~g}$ (Figure 2e). These pulp mass values indicate that on average $41 \%$ (from $13 \%$ to $69 \%$ ) of the fruit weight is composed of pulp. The yield of pulp is a very important characteristic when aiming the industrial use of the fruits. In guava-pear (Psidium acutangulum DC.) and jambolan [Syzygium cumini (L.) Skeels] the pulp yield ranging from 55 to $76 \%$ (Andrade et al., 1993) and 57 to $86 \%$ (Steiner et al., 2017), respectively. In cambuci [Campomanesia phaea (O. Berg) Landrum.] and araçá-boi (Eugenia stipitata McVaugh), the pulp yield of the fruits was 46 to $92 \%$ (Vallilo et al., 2005), and 63\% (Ferreira, 1992), respectively.

The number of seeds per fruit (NSF) ranging from 1 to 9 seeds (Table 1), with $66 \%$ of the fruits having 3 to 5 seeds (Figure 2f). The number of seeds per fruit is a characteristic of great importance for the reproduction of the species since the species present recalcitrant seeds (Schulz et al., 2014). According to Lorenzi (2002), the Inga laurina fruits contains on average 7.0 seeds. For the species Inga striata Benth., Mata et al. (2013) showed that the fruits have an average of 10 to 15 seeds.

For the traits obtained in the Inga laurina seeds, about $37 \%$ of the seeds have length values ranging from 18.5 to $20.0 \mathrm{~mm}$ (Figure 3a), with an average length of $17.58 \mathrm{~mm}$ (Table 1). The average value of seed width was $10.04 \mathrm{~mm}$, and $66 \%$ of the seeds had width values in three size classes (from 8.0 to $11.0 \mathrm{~mm}$ ) (Figure $3 \mathrm{~b}$ ). For the seed thickness, $77 \%$ of the seeds have values in three thickness classes from 7.0 to $9.1 \mathrm{~mm}$ (Figure 3c), with an average thickness of $8.32 \mathrm{~mm}$ (Table 1). For the seed fresh mass, $76 \%$ of the seeds have values in two weight classes from 0.86 to $1.10 \mathrm{~g}$ (Figure $3 \mathrm{~d}$ ), while the average weight was $0.95 \mathrm{~g}$ (Table 1). In Inga laurina fruits collected in the southern region of Brazil, Schulz et al. (2014) showed that the average seed weight ranged from 0.54 to $1.01 \mathrm{~g}$, while the length and width of the seeds were $10.0 \mathrm{~mm}$ and $7.90 \mathrm{~mm}$.

In addition to the study of the morphological characterization of fruits and seeds, it is also necessary to evaluate the association between these characteristics (Zuffo et al., 2016). These authors also report that the association between the characteristics is important because it allows to verify the degree of interference of a characteristic in another characteristic of economic interest, as well as to practice the indirect selection. In this context, the Spearman's rank correlation coefficient
(rS) is used to express the degree of association between two numerical characteristics. A positive or negative $\mathrm{rS}$ corresponds, respectively, to an increasing or decreasing monotonic trend between two variables ( $X$ and $Y$ ).

The values obtained for the $\mathrm{rS}$ of the physical characteristics of the I. laurina fruits and seeds indicated that there was a positive and significant association between the FL with the FFM, PFM, NSF and SFM. The FW correlated significantly with the FT, whereas the FT correlated significantly with the FFM, PFM, and NSF (Table 2). The FFM correlated significantly with the PFM, NSF and SFM. The PFM correlated significantly with the NSF and SFM, whereas the SL correlated significantly with the SW.

The highest values of the Spearman's correlation coefficients (rS) were observed between the FFM and PFM ( $\mathrm{rS}=0.919)$, between the fruit fresh mass FFM and NSF ( $\mathrm{rS}=0.737)$, between the FL and FFM ( $\mathrm{rS}=0.733)$, between FFM and SFM ( $\mathrm{rS}=0.676)$, and between FL and PFM ( $\mathrm{rS}=0.638)$ (Table 2). Based on these results is possible to identify and select Inga laurina fruits with higher pulp yield by other physical characteristics such as FFM and FL. Therefore, the selection of plants with fruits with greater weight and longer favors the breeding programs of the species, since these plants result in the increase of pulp yield.

On the other hand, there was a negative and significant correlation between FL with the SL; and between SL with the SW. These results indicate that there is an inversely proportional relationship between these characteristics. The knowledge of the degree of association between two variables allows defining the interference of the selection performed in one characteristic in another, as well as the indirect selection for difficult-to-measure characteristics (Zuffo et al., 2016). Thus, according to the results obtained in this study, it is possible to verify that some physical characteristics of the I. laurina fruits and seeds presented a high correlation, being possible to practice direct and indirect selection for these characteristics.

In general, the results presented here indicate that the species Inga laurina (Sw.) Willd. presents a variation in the size and weight of fruits, pulp, and seeds, which can be explored for breeding programs and should be considered in the formation of seed lots. The greater fruit pulp yield can be optimized with the selection of fruits with greater fresh mass and longer due to the high degree of association between these characteristics and the pulp yield. The length of the fruit is a good indication in the selection of seeds with greater weight. 

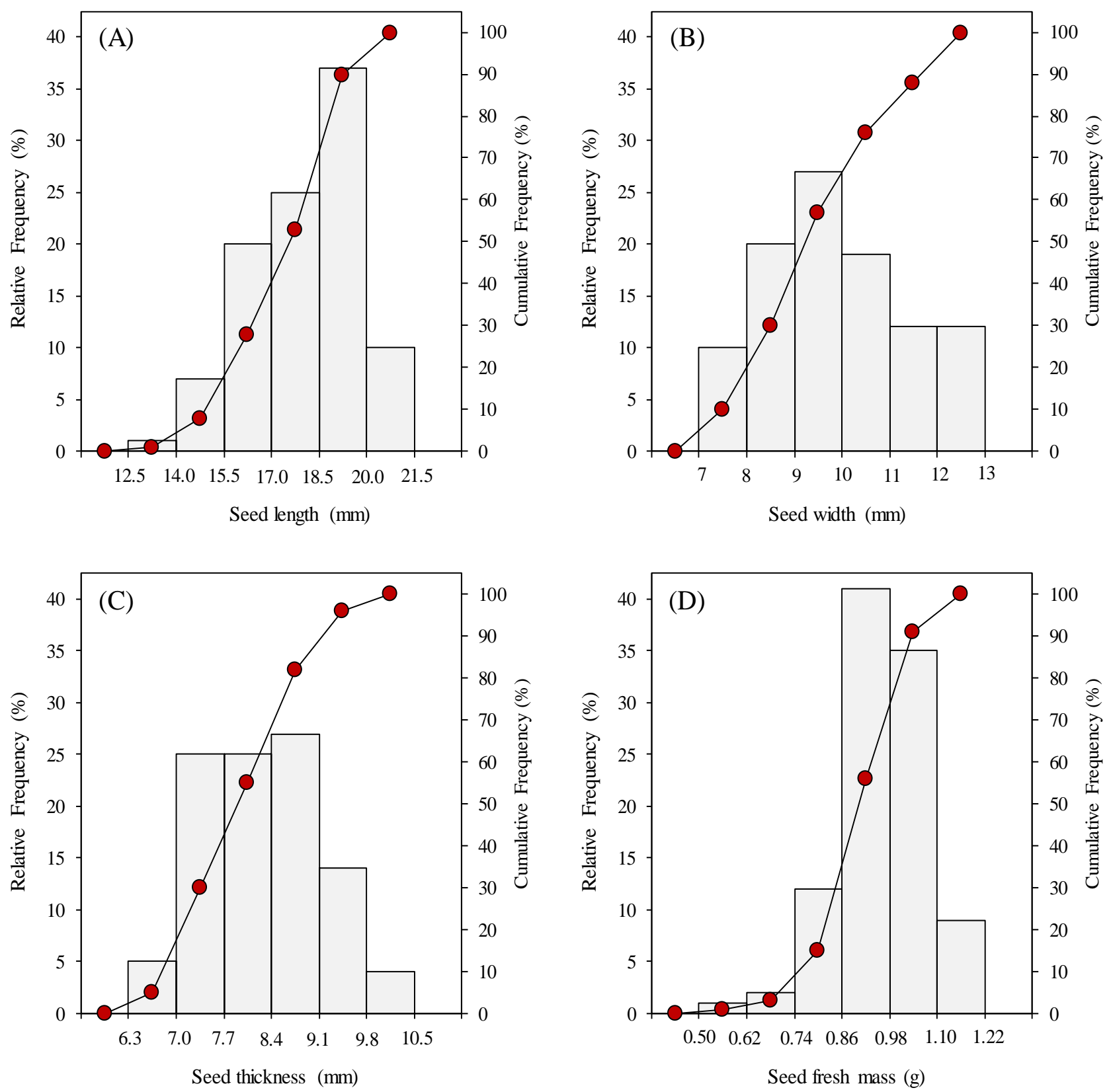

Figure 3. Distribution of relative and cumulative frequencies for the different physical characteristics of the seeds: a) length (SL), b) width (SW), c) thickness (ST), and d) fresh mass (SFM) of Inga laurina (Sw.) Willd. (Fabaceae - Mimosaceae) collected in the municipality of Cassilândia, MS, Brazil. $\mathrm{N}=100$ seeds.

Table 2. Spearman's rank correlation coefficient (rS) between the different physical characteristics of the Inga laurina (Sw.) Willd.] (Fabaceae - Mimosaceae) fruits and seeds collected in the municipality of Cassilândia, MS, Brazil.

\begin{tabular}{|c|c|c|c|c|c|c|c|c|c|}
\hline & FL & FW & FT & FFM & PFM & NSF & SL & SW & ST \\
\hline$\overline{\mathrm{FW}}$ & $-0.011^{\mathrm{NS}}$ & & & & & & & & \\
\hline FT & $0.095^{\mathrm{NS}}$ & $0.344 * *$ & & & & & & & \\
\hline FFM & $0.733 * *$ & $0.141^{\mathrm{NS}}$ & $0.334 * *$ & & & & & & \\
\hline PFM & $0.638 * *$ & $0.154^{\mathrm{NS}}$ & $0.362 * *$ & $0.919 * *$ & & & & & \\
\hline NSF & $0.456 * *$ & $-0.001^{\mathrm{NS}}$ & $0.205^{*}$ & $0.737 * *$ & $0.595 * *$ & & & & \\
\hline SL & $-0.306^{* *}$ & $0.048^{\mathrm{NS}}$ & $0.090^{\mathrm{NS}}$ & $-0.121^{\mathrm{NS}}$ & $-0.147^{\mathrm{NS}}$ & $-0.085^{\mathrm{NS}}$ & & & \\
\hline SW & $0.088^{\mathrm{NS}}$ & $0.177^{\mathrm{NS}}$ & $0.120^{\mathrm{NS}}$ & $0.085^{\mathrm{NS}}$ & $0.167^{\mathrm{NS}}$ & $-0.163^{\mathrm{NS}}$ & $-0.276^{* *}$ & & \\
\hline ST & $0.041^{\mathrm{NS}}$ & $-0.020^{\mathrm{NS}}$ & $-0.121^{\mathrm{NS}}$ & $0.023^{\mathrm{NS}}$ & $0.012^{\mathrm{NS}}$ & $0.135^{\mathrm{NS}}$ & $0.184^{\mathrm{NS}}$ & $0.189^{\mathrm{NS}}$ & \\
\hline SFM & $0.387 * *$ & $0.039^{\mathrm{NS}}$ & $0.177^{\mathrm{NS}}$ & $0.676^{* *}$ & $0.526^{* *}$ & $-0.186^{\mathrm{NS}}$ & $-0.055^{\mathrm{NS}}$ & $-0.029^{\mathrm{NS}}$ & $0.070^{\mathrm{NS}}$ \\
\hline
\end{tabular}

NS: not significant. *: $P=0.05$. **: $P=0.01$. FL: fruit length. FW: fruit width. FT: fruit thickness. FFM: fresh fruit mass. PFM: pulp fresh mass. NSF: number of seeds per fruit. SL: seed length. SW: seed width. ST: seed thickness. SFM: seed fresh mass. 


\section{Bibliographic References}

Andrade, J.S., Aragão, C.G., Ferreira, S.A.N., 1993. Caracterização física e química dos frutos de araçá-pêra (Psidium acuntangulum D.C.) Acta Amazonica, 23, 213-217.

Aquino, N.F., Ajala, M.C., Dranski, J.A., Ignácio, V.L., Malavasi, M.M., Malavasi, U.C., 2009. Morfometria de sementes de Jatropha curcas L. em função da procedência. Revista de Ciências Agroveterinárias, 8, 142-145.

Ayres, M., Ayres-Júnior, M., Santos, A.A.S., 2007. BioEstat 5.0: Aplicações estatísticas nas áreas das ciências biológicas e médicas. Belém: Sociedade Civil Mamirauá.

Bonjovani, M.R., Barbedo, C.J., 2008. Sementes recalcitrantes: intolerantes a baixas temperaturas? Embriões recalcitrantes de Inga vera Willd. subsp. affinis (DC.) T. D. Penn. toleram temperatura sub-zero. Revista Brasileira de Botânica, 31, 345-356.

Ferreira, S.A.N., 1992. Biometria de frutos de araçá-boi (Eugenia stipitata McVaugh). Acta Amazonica, 22, 295-302.

Fonseca, S.C.L., Freire, H.B., 2003. Sementes Recalcitrantes: Problemas na pós-colheita. Bragantia, 62, 297-303.

Gusmão, E., Vieira, F.A., Fonseca-Júnior, E.M., 2006. Biometria de frutos e endocarpos de murici (Byrsonima verbascifolia Rich. ex A. Juss.). Cerne, 12, 84-91.

Lorenzi, H., 2002. Árvores Brasileiras: manual de identificação e cultivo de plantas arbóreas do Brasil, vol. 2, segunda ed. Nova Odessa, SP: Instituto Plantarum.

Lorenzi, H., Bacher, L., Lacerda, M., Sartori, S. 2006. Frutas brasileiras e exóticas cultivadas: de consumo in natura. São Paulo: Instituto Plantarum de Estudos da Flora.

Mata, M.F., Silva, K.B., Bruno, R.L.A., Felix, L.P., Medeiros Filho, S., Alves, E.U., 2013. Maturação fisiológica de sementes de ingazeiro (Inga striata) Benth. Semina: Ciências Agrárias, 34, 549-566.

Pennington, T.D., 1997. The genus Inga - Botany. Kew, Royal Botanic Gardens.

Rebouças, E.R., Gentil, D.F.O., Ferreira, S.A.N., 2008. Caracterização física de frutos e sementes de goiaba-da-costa- rica, produzidos em Manaus, Amazonas. Revista Brasileira de Fruticultura, 30, 546-548.

Rodrigues, A.C.C., Osuna, J.T.A., Queiroz, S.R.O.B., Rios, A.P.S., 2008. Biometria de frutos e sementes e grau de umidade de sementes de angico (Anadenanthera colubrina (Vell.) brenan var. cebil (Griseb.) Altschul) procedentes de duas áreas distintas. Revista Científica Eletrônica de Engenharia Florestal, 4, 1-15.

Schulz, D.G., Oro, P., Volkweis, C., Malavasi, M.M., Malavasi, U.C., 2014. Maturidade fisiológica e morfometria de sementes de Inga laurina (Sw.) Willd. Floresta e Ambiente, $21,45-51$.

Souza, V.C., Lorenzi, H., 2005. Botânica Sistemática: Guia ilustrado para identificação das famílias de angiospermas da flora brasileira, baseado em APGII. Nova Odessa: Instituto Plantarum.

Steiner, F., Zuffo A.M., Zoz, T., 2017. Physical characterization of fruits and seeds of jambolan [Syzygium cumini (L.) Skeels] (Myrtaceae). Acta Iguazu, 6, 79-90.

Vallilo, M.I., Garbelotti, M.L., Oliveira, E., Lamardo, L.C.A., 2005. Características físicas e químicas dos frutos de cambucizeiro (Campomanesia phaea). Revista Brasileira de Fruticultura, 27, 241-244.

Zar, J.H., 1996. Biostatistical analysis, quarta ed. River, Prentice-Hall/Upper Saddle, New Jersey.

Zuffo, A.M., Andrade, F.R., Zuffo-Júnior, J.M., 2014. Caracterização biométrica de frutos e sementes de baru (Dipteryx alata Vog.) na região leste de Mato Grosso, Brasil. Revista de Ciências Agrárias, 37, 463-471.

Zuffo, A.M., Gesteira, G.S., Zuffo-Júnior, J.M., Andrade, F.R., Soares, I.O., Zambiazzi, E.V., Guilherme, S.R., Santos, A.S., 2016. Caracterização biométrica de frutos e sementes de mirindiba (Buchenavia tomentosa Eichler) e de inajá (Attalea maripa [Aubl.] Mart.) na região sul do Piauí, Brasil. Revista de Ciências Agrárias, 39, 455-472.

Zuffo, A.M., Steiner, F., Zoz, T., Zuffo-Júnior, J.M., Douradinho, G.Z., Oliveira, C.P., Bortolazzo, G., 2017. Atributos biométricos de frutos e sementes de Peltophorum dubium (Spreng.) Taub. Revista de Ciências Agrárias, 40, 6267. 